\title{
Computer Modeling Deformation of Porous Elastoplastic Materials and Identification their Characteristics Using the Principle of Three-dimensional Similarity
}

\author{
Valentin G. Bazhenov* \\ Maxim N. Zhestkov ${ }^{\dagger}$ \\ Nizhny Novgorod State Lobachevski University \\ Nizhny Novgorod, Russian Federation
}

Received 9.06.2021, received in revised form 9.07.2021, accepted 8.08.2021

\begin{abstract}
It is proposed to numerically model large deformations of porous specimens, using the 3Dsimilarity principle in structural elements, which makes it possible to account for the inhomogeneity of the stress-strain state due to the presence of pores and allows one to vary the number of representative volumes without changing porosity values and dimensions of the specimens. A methodology for determining true deformation diagrams of materials, using the results of compression tests, has been developed. The efficiency of using the 3D-similarity principle is demonstrated by comparing the numerical and experimental results for the example analyzing compression of porous specimens of an aluminum alloy with free lateral surfaces and fixed in a rigid cartridge.
\end{abstract}

Keywords: porous metal, diagramm of deformation, deformation, 3D-similarity principle, structural element.

Citation: V.G. Bazhenov, M. N.Zhestkov, Computer Modeling Deformation of Porous Elastoplastic Materials and Identification their Characteristics Using the Principle of Three-dimensional Similarity, J. Sib. Fed. Univ. Math. Phys., 2021, 14(6), 746-755. DOI: 10.17516/1997-1397-2021-14-6-746-755.

\section{Introduction}

Porous materials are widely used in technology as they are characterized by low weight, high thermal and electric conductivity and possess excellent damping properties. That is why stressstrain state analysis of porous structures is a topical issue in designing various structures. The majority of scientific works and articles treat porous materials as solid with equivalent strength characteristics. In [1-7], empirical formulas are introduced for materials with porosity values of 0.2 to 0.4 that make it possible to evaluate the decrease of strength of a porous structure, knowing the corresponding parameter of the basic material. However, no such evaluations are found in the literature for porosities of over 0.4. The analysis where a porous structure is approximated with a solid material with equivalent strength characteristics does not account for the inhomogeneity of stress-strain state due to the presence of pores. It is noted in [12-13] that pore geometry affects strength characteristics of a structure as a whole, testifying to the importance of accounting for geometrical inhomogeneity when analyzing deformation processes in porous materials. This problem is overcome by defining the internal structure of a porous body, using various methods

\footnotetext{
*bazhenov@mech.unn.ru

$\dagger$ mnzhestkov@yandex.ru

(c) Siberian Federal University. All rights reserved
} 
of studying spatial porous structures [8-11]. Based on the information obtained, the geometry of a representative volume is reconstructed. Modern numerical methods make it possible to model deformation, based on a precise geometrical model of a porous structure [14-15]. In [14], a geometrical model of the porous structure of a $0.4 ? 0.4 ? 0.4 \mathrm{~mm}$ cube is described using about 800 thousand finite elements. Such an approach requires a huge amount of computational resources and is hardly practical in analyzing large structures.

Inhomogeneity of the stress-strain state of a representative volume can be accounted for by using the 3D-similarity principle formulated by Kirpichyov [16] for elastic bodies and later extended by Kick to elastoplastic materials. The principle can be formulated as follows: when geometrically similar bodies of the same material are deformed in similar loading conditions, the resulting stresses and strains in the structure are identical. This makes it possible to replace a set of identical representative volumes with one structural element, geometrically similar to them (see Fig. 1), where an average stress-strain state for the given set is implemented.

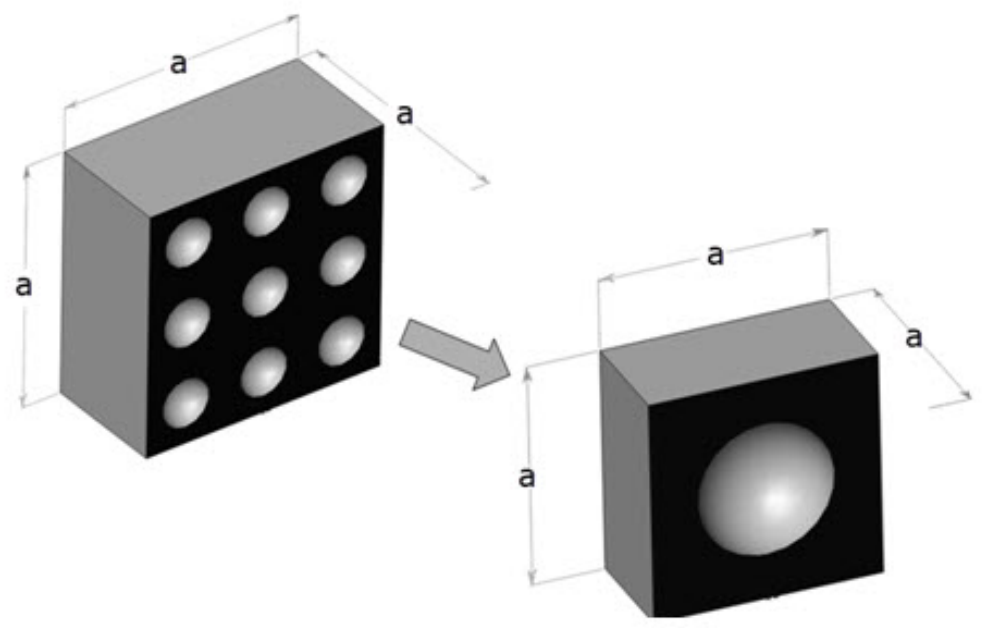

Fig. 1. Replacing a structural element with a geometrically similar one, using the 3D-similarity principle

Such an approach makes it possible to account for the inhomogeneity of stress-strain state in a structural element without changing the porosity value and characteristic dimensions of the deformed body. This enables one to control the bulk of computational task by varying the number of structural elements. Papers [17-18] demonstrate the effectiveness of the 2D-similarity principle in numerically analyzing bending and stability of densely perforated plates and shells.

In the process of porous metal forming, with sintering and decomposition of the porous form, the basic material is subjected to the effects of high temperatures and chemical reactions leading to changes in its strength characteristics. Analysis of deformation of porous metals, taking into account their geometrical inhomogeneity, requires knowledge of a true deformation diagram of the basic material. Experimental determination of strength characteristics of basic materials appears quite difficult. The numerical-experimental method $[19,20]$ developed in the Research Institute for Mechanics, Nizhny Novgorod Lobachevski State University, makes it possible to identify a true deformation diagram of the basic material, using modern numerical methods and experimental data on compression of porous specimens in combination with the 3D-similarity principle. 
The present paper describes a method of identifying strength characteristics of the basic material of a porous material and presents the results of assessing the effectiveness of applying the 3D-similarity principle to analyzing problems of static compression of porous specimens.

\section{Identifying the deformation diagram of the basic material}

A deformation diagram of the basic material is reconstructed using experimental data on static compression of porous specimens in a rigid cartridge. $20 \mathrm{~mm}$-high $30 \mathrm{~mm}$-dia cylindrical specimens were used in the tests. Initial porosity of the specimen in the experiment was defined as a ratio of the porosities of the porous and solid specimens and amounted to 0.64. Maximal values of engineering strain of compressed specimens were up to $45 \%$. No contact interaction of the pore banks was observed. The deformation diagram of the basic material was reconstructed using the methodology proposed in $[19,20]$. Due to the presence of cavities, porous aluminum has a geometrically complex internal structure and as a result, a variable cross-section, both in the non-deformed state and during compression. The true deformation diagram of the basic material was reconstructed iteratively. At each iteration step, the relation between the intensity of true stresses $\sigma_{i}$ and the intensity of logarithmic strains ei was updated so that it agreed, to an assigned accuracy, with the experimental relation between the compressive force and the displacement of the gripping device of the testing machine. To this end, updating function $\alpha(\mathrm{e})$ is constructed

$$
\alpha(e)=\frac{F_{e}(e)}{F_{n m}(e)}
$$

$F_{e}(e)$ is experimental relation between compressive force and relative change of the length of the specimen, $\mathrm{N}$;

$F_{n m}(e)$ is numerically modeled relation between the compressive force and the relative change of the length of the specimen, $\mathrm{N}$;

$e=\frac{u}{L}$ is relative change of the length of the specimen;

$\mathrm{u}$ is displacement of the upper end of the specimen, $\mathrm{m}$;

$\mathrm{L}$ is initial length of the specimen, $\mathrm{m}$; As a result of numerical modeling, the relation between maximal value of strain intensity $e_{i}^{\max }(e)$ and relative change of thelength of the specimen is determined. The true deformation diagram is updated using the formula:

$$
\sigma_{i}\left(e_{i}^{\max }\right)=\alpha \sigma_{i}\left(e_{i}^{\max }\right) .
$$

Updating is iterated until relations $F_{e}(e)$ and $F_{n m}(e)$ agree to an accuracy of $5 \%$.

A cubic structural element with an internal globular pore was chosen for modeling. The porosity coefficient is defined as the ratio of the volumes of the cavity and of the cube defining the structural element. The initial porosity of the specimen used in the tests was 0.64. The required porosity value is obtained, choosing a cavity in the form of a cube with smoothed ribs and apexes. Fig. 2 depicts a geometrical model of a structural element that made it possible to account for loss of stability in the membranes between the pores.

In modeling static compression of a porous specimen in a rigid cartridge, it was assumed that all the elements are deformed similarly. Thus, only one column of the five representative volumes was used in the analysis. The height of the column was $20 \mathrm{~mm}$. Compression of the porous structure was modeled using the finite element method, with the Abaqus software complex [21]. The finite-element model of one structural element consisted of 14240 cells. The C3D8R lagrangian finite element was used in the analysis. 


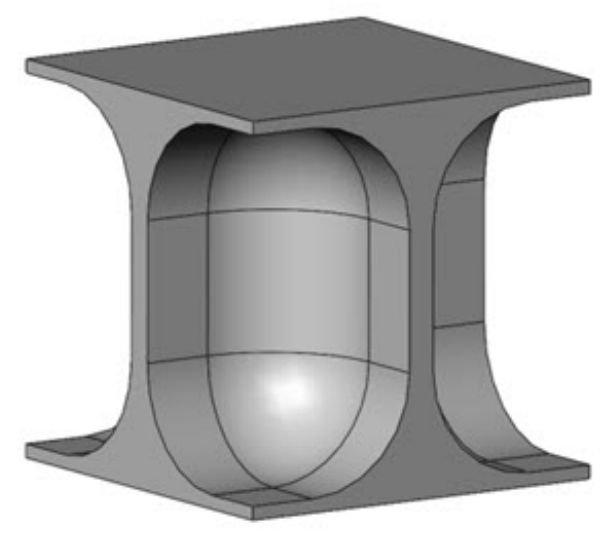

Fig. 2. Structural element

Along the lower end of the analyzed column of structural elements, the value of vertical displacements was assigned to be zero, whereas along the upper end, constant velocity of vertical displacements was prescribed. The compression rate was equal to $1 \mathrm{~mm} / \mathrm{s}$, making it possible to neglect any non-stationary effects. Along the lateral surfaces, zero values of normal displacements and tangential stresses were assigned in the analysis. Time integration was done using the crosstype explicit scheme.

Fig. 3a presents true deformation curves after 4 updating iterations; Fig. 3b shows the change of the relation between compressive force and relative displacement of the upper end of the specimen.

Fast convergence of the iterative process is observed, as only 4 iterations suffice to achieve the accuracy of less than $5 \%$. The described scheme makes it possible to identify the deformation curve of the basic material for porous specimens with initially homogeneous structure in the presence of large strains and inhomogeneous stress-strain states of various types (tension, compression, shear). If contact interaction of pore banks is taken into account, a deformation diagram may be constructed up to the moment of pore collapse and then continued with accounting for friction of the contacting surfaces.

To assess the accuracy of the constructed deformation diagram obtained using five structural elements, compression of columns of 10 and 20 representative volumes was numerically analyzed. The dimensions of the elements were chosen so that the height of a column was $20 \mathrm{~mm}$ independently of the number of structural elements. The relation between true stresses and strains in the basic material was defined with a reconstructed deformation curve. The formulation of the problem of numerical analysis is analogous to that for a column of 5 structural elements in a rigid cartridge. Fig. 4 shows the diagram of the change of compressive force, reduced to the cross-section area of the specimen, as a function of relative displacement of the upper end and the number of structural elements along the compression axis. The results of the analyses using 5,10 and 20 structural elements differ by less than $1 \%$, and the difference between the calculated forces and the experimental data is within $5 \%$. Thus, a column of 5 structural elements is sufficient for reconstructing a deformation curve of the basic material.

Numerical analysis showed that, for geometrical models with the number of representative volumes more than 5 , the calculated stress-strain state is identical in all the structural elements except for the boundary ones, where the 3D-similarity principle is violated due to the fact that 


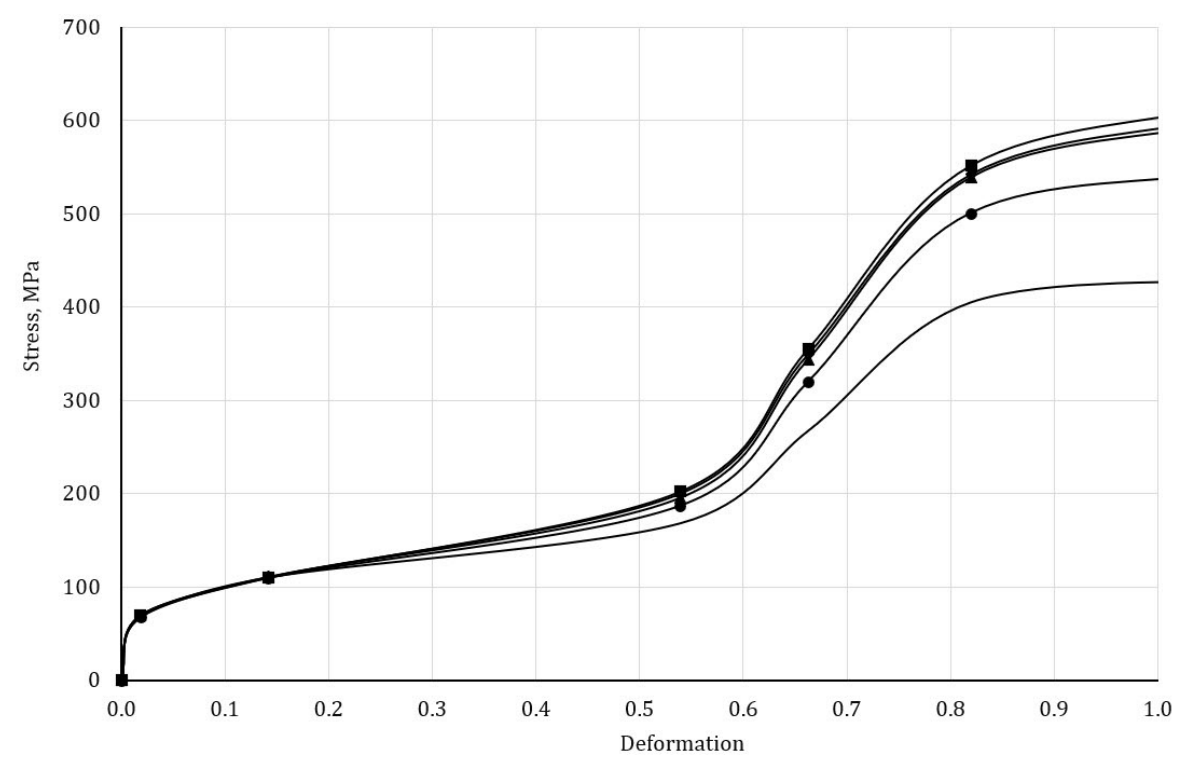

a. deformation curve

— inital diagramm; - 1 iteration, $\_$iteration, $\bullet-3$ iteration, $\bullet-4$ iteration

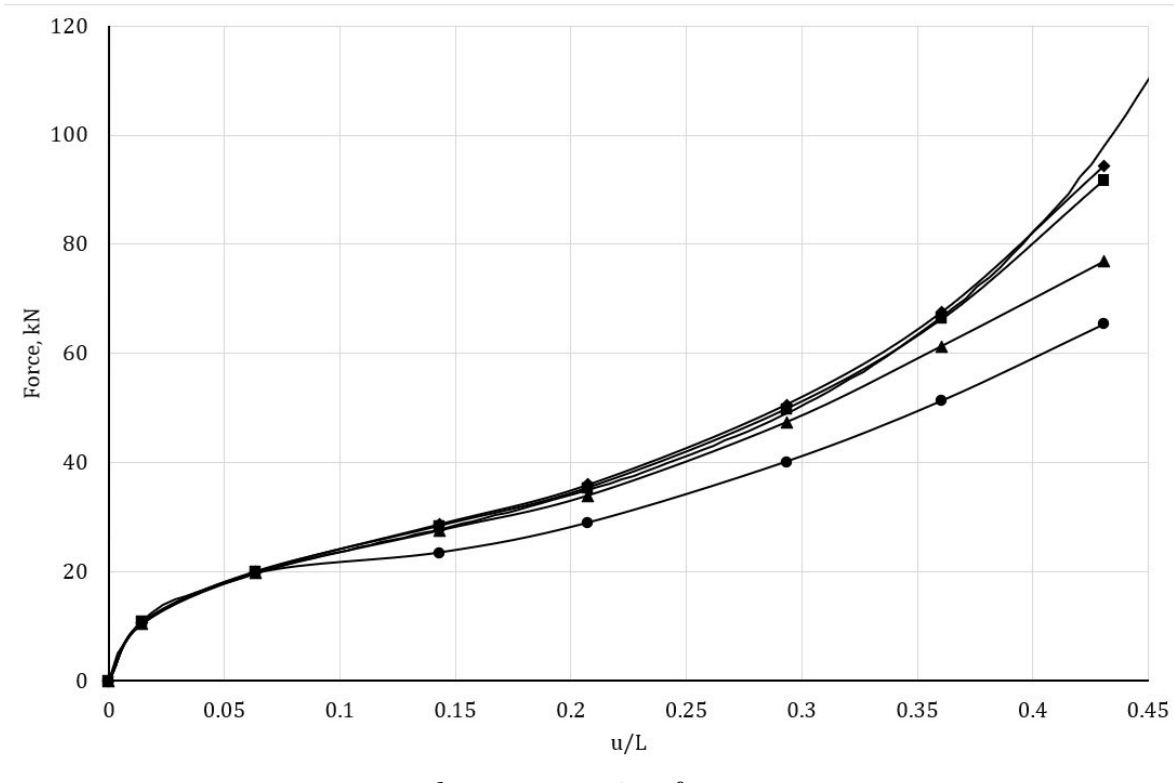

b. compressive force

- experiment; $\bullet-1$ iteration, $\_-2$ iteration, $\_3$ iteration, $\bullet 4$ iteration

Fig. 3. Iterative procedure of identifying the material properties

constant displacement velocity is assigned along their ends. Compression causes local loss of stability along the membranes between the pores with the relative displacement of the moving end equal to 0.1. Local loss of stability takes place in all the internal structural elements simultaneously.

The average dimension of a structural element in the tested specimen was about $0.3 \mathrm{~mm}$. Use 


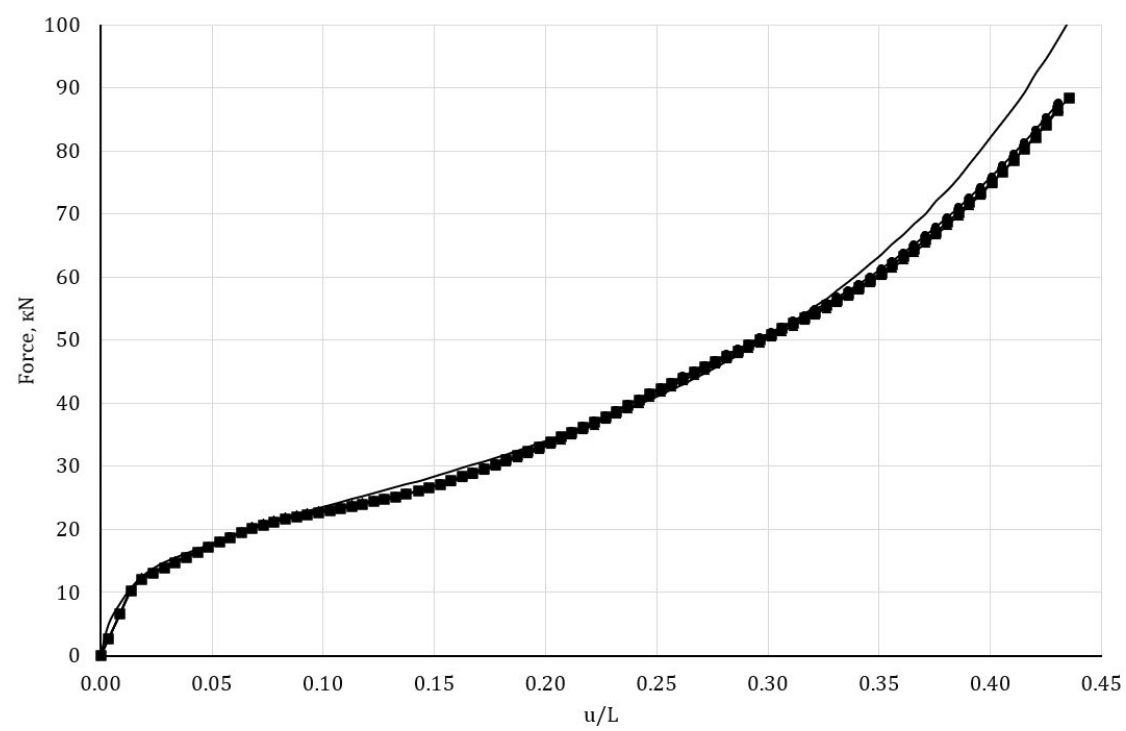

Fig. 4. Compressive force as a function of the number of structural elements: - experiment, - 5 elements, $\_10$ elements, -20 elements

of the 3D-similarity principle for the porous material made it possible to conduct the identification of the deformation curve of the basic material, using a column of 5 structural elements. To analyze a $20 \mathrm{~mm}$-high porous specimen without using the similarity principle, it would be necessary to consider a column of 67 structural elements $0.3 \mathrm{~mm}$ high each.

\section{Analyzing compression of porous specimens with free lateral surfaces}

Static compression of a porous body with free lateral surfaces was experimentally studied using a $20 \mathrm{~mm}$-high $70 \mathrm{~mm}$-dia cylindrical specimen. As in the case of compression tests with a specimen in a rigid cartridge, the maximal strain values did not reach the degree when interaction of the pore banks takes place. Initial porosity of the specimen was 0.64 .

The geometrical models for the analyses were constructed based on the form of the structural element (Fig. 5) and the geometrical characteristics of the experimental specimen. The geometry of the structural element makes it possible to construct the analyzed region in the form of a parallelepiped. That is why the geometrical models were constructed so that the height was $20 \mathrm{~mm}$, and the cross-sectional areas of the constructed analyzed region and of the experimental specimen closely corresponded to each other. The cross-sectional area of the constructed geometrical model differed from that of the experimental specimen only by $6 \%$. Geometrical models with 9, 72 and 243 structural elements were considered. To minimize the computational task, the geometrical symmetry was taken into account, and only $1 / 4$ of the structure was analyzed. The structural elements were positioned so that the surfaces cutting off $1 / 4$ of the specimen crossed the centers of the cavities. In that case, the geometrical model of a porous structure makes it possible to account for local loss of stability in the compressed membranes between the cut off pores. Fig. 5 depicts the analyzed geometrical models of the porous specimen.

Compression of the porous specimens was modeled using two ideally solid bodies located at 


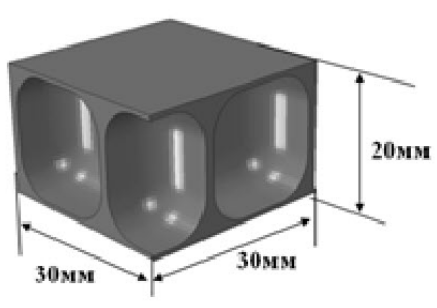

a. 9 elements

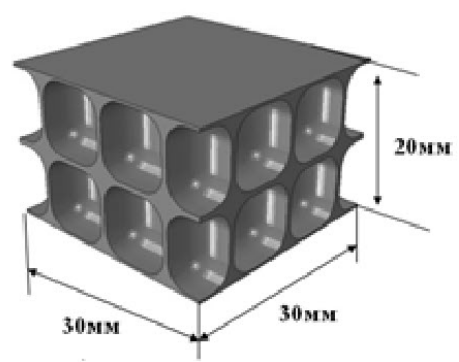

b. 72 elements

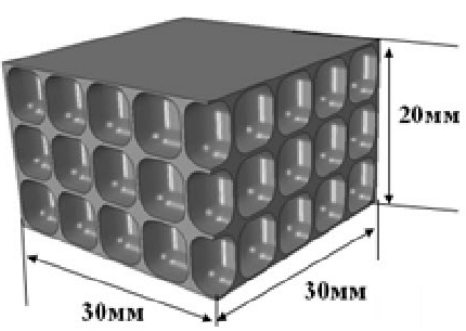

b. 243 elements

Fig. 5. Geometrical models of a porous specimen

the ends of the specimen. One of the ideal solids moved at a velocity of $1 \mathrm{~mm} / \mathrm{s}$, while the second one was motionless. The contact interaction condition over the surfaces of the bodies and of the considered region, contacting one another, was defined, accounting for friction, which is described by Coulomb law with the friction coefficient of 0.1 . Over the surfaces cutting off $1 / 4$ of the considered region, zero normal displacements and tangential stresses were assigned. The loading scheme is presented in Fig. 6.

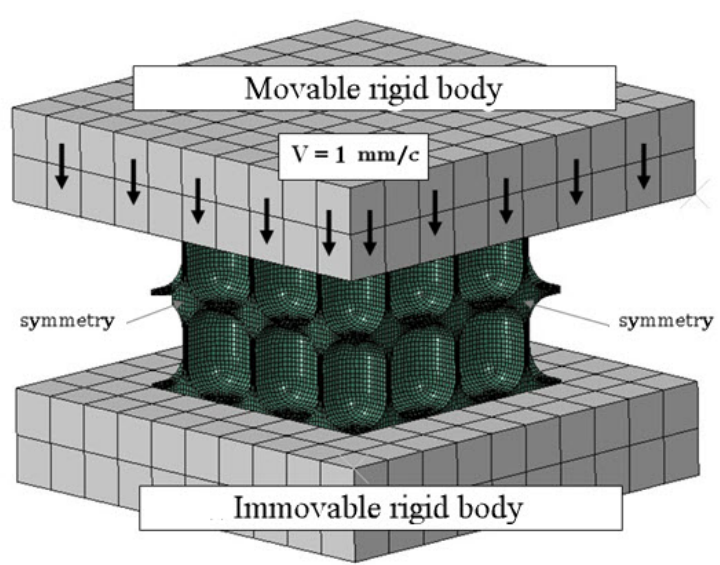

Fig. 6. Loading scheme modeling compression of porous bodies with free lateral surfaces

The behavior of the elastoplastic basic material was described by a true deformation curve that was identified based on the experimental data on compression of a porous specimen in a rigid cartridge.

Fig. 7 shows compressive force reduced to the cross-sectional area of the experimental specimen as a function of relative displacement of the upper end and the number of structural elements.

Maximal inaccuracies of the numerical analysis (6\%) as compared with the experimental data are observed for the 9-element model. For the 72- and 243-element models, the computational error for compressive force is within 5\%. Numerical modeling revealed that, for geometrical models with 72 and 243 representative volumes, differences in the stress-strain state in the structural elements arise as the distance from the center of the geometrical model increases. Local loss of stability in the membranes occurs when the relative displacement of the movable 


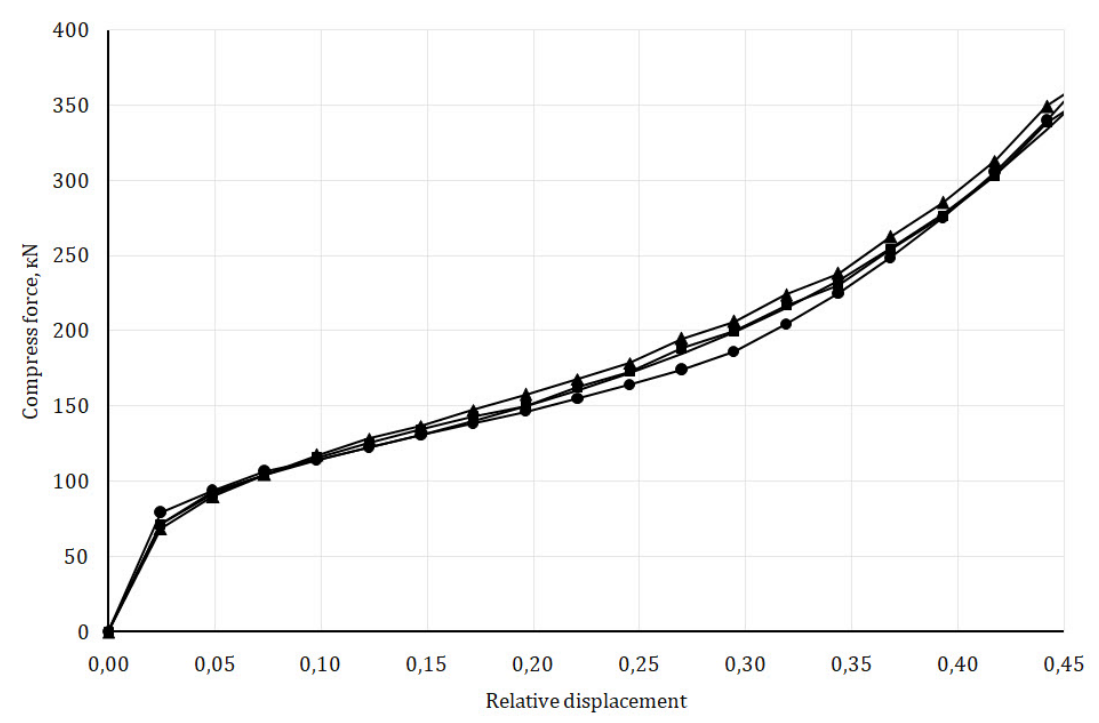

Fig. 7. Compressive force as function of relative displacement of the upper end of a specimen with free lateral surfaces: - experiment, $\bullet 9$ elements, $\_72$ elements, -243 elements

end reaches 0.06 . First, loss of stability takes place in the membranes of the structural elements belonging to the lateral free surfaces. As compression of the specimen continues, the internal structural elements lose stability. The membranes in the structural elements situated in the center of the geometrical model lose stability at the last moment. The computational results using 9,72 and 243 structural elements differ not more that by $9 \%$, their difference from the experimental data being within 6 Numerical analysis of compression of a porous specimen with free lateral surfaces, accounting for the true dimensions of a representative volume $(0.3 \mathrm{~mm})$, would require about 187 thousand structural elements. Use of the 3D-similarity principle made it possible to conduct numerical analysis of compression of a porous specimen with a reasonable accuracy, using only 9 structural elements.

\section{Conclusion}

The efficiency of using the 3D-similarity principle in the numerical analysis of compression of specimens of porous aluminum was studied. The above principle makes it possible to account for the inhomogeneity of stress and strain distributions in the presence of cavities and to reduce the computational task by varying the number of structural elements, while retaining the porosity coefficient and characteristic dimensions of the structure. In the numerical analysis of compression of a cylindrical specimen of porous aluminum in a rigid cartridge, using the explicit time integration scheme, the application of the 3D-similarity principle made it possible to reduce the computational task by two orders of magnitude, and in modeling compression of a specimen with free lateral surfaces by 5 orders. It took only 4 hours to analyze inhomogeneous stress-strain state of specimens of porous aluminum on a local 4-kernel PC.

The work was done with financial support from Grant №20-08-00667 of the Russian Fund for Fundamental Researches. 


\section{References}

[1] P.G.Cheremskoy, Metody issledovaniya poristosty tverdyh tel, M., Energoatomizdat, (1985), 112 (Russian).

[2] A.A.Vityaz, V.M.Kaptsevich, A.G.Kostornov, Formirovanie struktury i svoistv poristyh poroshkovyh materialov, M., Metallurgiya, (1993), 240 (Russian).

[3] A.Ya.Krasovskiy, Nekotorye zakonomernosti deformirovaniya i razrusheniya poristyh metallokeramicheskih materialov na osnove zheleza. Soobshchenie 1, Poroshkovaya metallurgiya, 4(1964), 3-7 (Russian).

[4] A.Ya.Krasovskiy, Nekotorye zakonomernosti deformirovaniya i razrusheniya poristyh metallokeramicheskih materialov na osnove zheleza. Soobshchenie 2, Poroshkovaya metallurgiya, 5(1964), 9-15 (Russian).

[5] V.V.Skorokhod, L.M.Tuchinskiy, Uslovie plastichnosti poristyh tel, Poroshkovaya metallurgiya, 11(1978), 83-87 (Russian).

[6] L.J.Gibson, M.F.Ashby, Cellular Solids structure and properties, Pergamon Press., Oxford, (1988), 503.

[7] E.Andrews, W.Sanders, L.J.Gibson, Compressive and tensile behavior of aluminum foams, Materials Science and Engineering,, A270(1999), 113-124.

[8] V.V.Polyakov, A.V.Golovin, Moduli uprugosti poristyh materialov, FMM, RAN, T.79.V.2(1995), 57-60 (Russian).

[9] V.V.Polyakov, A.V.Golovin, Vliyanie poristosti nd uprugie harakteristiki metalla, Metally, 4(1995), 81-85 (Russian).

[10] K.S.Chernyavskiy, Stereologiya v metallovedenii, M., Metallurgia, (1977), 280 (Russian).

[11] R.Bradford, T.M.Dofine, H.Preston-Thomas, Pribory i methody fizicheskogo metallovedeniya, M., Mir, (1973), 786 (Russian).

[12] J.Banhart, J.Baumeister, Deformation characteristics of metal foams, Journal of mat. Science, V.33(1998), 1431-1440.

[13] H.Bart-Smith, A.F.Bastawros, A.G.Evans and other, Compressive deformation and yielding mechanisms in cellular Al alloys determined using X-ray tomografy and surface strain mapping, Acta mat., V.46,n.10(1998), 3583-3592.

[14] M.Dorozhko, A.Seweryn, Finite Element Modeling of Anisotropic Deformation Behavior of the Porous Materials Based on Microtomographic Images, AIP Conference Proceedings 1780,, (2016), P.060001.

[15] M.Dorozhko,A.Seweryn, Pore-scale numerical modelling of large deformation behaviour of sintered porous metals under compression using computed microtomography, Mechanics of Materials, ISSN 0167-6636, e-ISSN 1872-7743(2019), 1-18.

[16] V.L.Kirpichyov, O podobii pri uprugih yavloniyah, Zhurnal Russkogo fiziko-himicheskogo obshchestva, T. 6, vyp. 9,(1874), 90-120 (in Russian) 
[17] V.G.Bazhenov, M.N.Zhestkov, ( Issledovanie primenimosti printsipa podobiya v zadachah uprugoplasticheskogo izgiba i ustoychivosti pri osevom szhatii gusto perforirovannyh plastin i obolochek), Sbornik: Materialy XII Mezhdunarodnoy konferentsii po prikladnoy matematike I mehanike v aerokosmicheskoy otrasli (NPNJ'2018), (2018), 326-328 (in Russian).

[18] V.G.Bazhenov, M.N.Zhestkov, About the applicability limits of the tymoshenko model and the principle of two-dimensional similarities in problems of elastic plastic bending and stability of densely perforated plates and shells, Journal of physics: conference series 1158, (2019), 022022 .

[19] V.G.Bazhenov, S.L.Osetrov, D.L.Osetrov, A.A.Artemyeva, Influence of the type of stressstrain state on the true stress-strain curve for the elastoplastic materials, Materials physics and mechanics, 28(2016), no. 1-2, 53-56.

[20] V.G.Bazhenov, V.K.Lomunov, S.L.Osetrov, E.V.Pavlenkova, Eksperimentalno-raschetniy metod issledovaniya bolshyh uprugoplasticheskih deformatsiy tsilindricheskih obolochek pri rastyazhenii do razryva i postroenie diagram deformirovaniya pri neodnorodnom napryazhenno-deformirovannom sostoyanii, Prikladnaya mehanika $i$ tehnicheskaya fizika, (2013), no. 1, 116-124 (in Russian).

[21] Abaqus Analysis User's Guide. Abaqus Theory Guide, Simulia Abaqus, 2016.

\title{
Компьютерное моделирование деформирования пористых упругопластических материалов и идентификация их характеристик с использованием принципа трехмерного подобия
}

\author{
Валентин Г. Баженов \\ Максим Н. Жестков \\ Нижегородский государственный университет им. Н. И. Лобачевского \\ Нижний Новгород, Российская Федерация
}

\begin{abstract}
Аннотация. Предложено осуществлять численное моделирование больших деформаций пористых образцов с использованием принципа трехмерного подобия в структурных элементах, который позволяет учесть неоднородность напряженно-деформированного состояния, вызванного наличием пор, и дает возможность изменять количество представительных объемов, сохраняя значения пористости и размеры образцов. Разработана методика определения истинной диаграммы деформирования материала основы пористого образца с использованием результатов испытаний на сжатие. На примере численного исследования сжатия пористых образцов из алюминиевого сплава со свободными боковыми поверхностями и закрепленных в жесткой обойме показана эффективность применяемого принципа трехмерного подобия путем сравнения численных и экспериментальных данных.
\end{abstract}

Ключевые слова: пористый металл, диаграмма деформирования, принцип трехмерного подобия, структурный элемент. 